\title{
Kırsal Alanda Sosyal Destek Projesi (Kasdep) Kapsamında Kurulan Damızlık Sığır Yetiştiriciliği Kooperatiflerinin Genel Durumu, Sorunları ve Çözüm Önerileri (Şanlıurfa Örneği)
}

\author{
Gönül SEViNÇ ${ }^{{ }^{*}}$, Turan BiNici² \\ ${ }^{1}$ Harran Üniversitesi, Suruç Meslek Yüksekokulu, Şanlıurfa \\ ${ }^{2}$ Harran Üniversitesi, Ziraat Fakültesi, Tarım Ekonomisi Bölümü, Şanlıurfa \\ *Sorumlu yazar: gsevinc@harran.edu.tr
}

Öz

Şanlıurfa ili sınırları içerisinde bulunan Harran Ovası; bereketli toprağıyla sadece bitkisel üretim için değil, hayvansal üretim için de oldukça avantajlı imkânlara sahip olan bir alandır. Bununla beraber Şanlıurfa ili kırsal alanında yoksulluğun da ciddi olarak hissedildiği bir ildir. 2003 yılında, Gıda Tarım ve Hayvancılık Bakanlığı ile Sosyal Yardımlaşma ve Dayanışma Genel Müdürlüğü arasında imzalanan bir protokol; ile Kırsal Alanda Sosyal Destek Projesi (KASDEP) uygulanmaya konmuştur. Bu proje ile 2005 yilından sonra Şanlıurfa'da ortalama 80 - 90 üyeli, 19 damızlık sığır yetiştiriciliği kooperatifi kurulmuştur. Ancak bu kooperatiflerin tamamı şu an faaliyetlerini sonlandırmış olup, kullanılan devlet kredilerini geri ödeyemeyerek icra takibi durumuna düşmüşlerdir. Bu çalışmada; KASDEP kapsamında Şanlıurfa'da kurulan damızlık sığır yetiştiricisi kooperatifler araştırıımıştır. Araştırma sürecinde kooperatif yöneticileri ve üyeleri ile odak grup görüşmeleri yapılmıştır. Görüşmeler ile elde edilen veriler, gözlemler ve değerlendirmeler sonucunda; KASDEP kapsamında kurulan damızık sığır yetiştiriciliği kooperatiflerinin genel durumları, sorunları ve kapanma nedenleri tespit edilmiştir. Bu tespitler ışığında; özellikle Şanlıurfa'da damızlık sığır yetiştiriciliği ve tarım kooperatiflerinin faaliyetlerinin başarılı olması için, yapılması gereken uygulamalar ve izlenmesi gereken politikalar önerilmiştir.

Anahtar Kelimeler: Şanlıurfa, Tarımsal Örgütlenme, Kooperatif, Hayvancılık

\section{General Situation of Breeding Cattle Cooperatives Founded With in The Context of Social Support Project at The Rural Area, The Problems and Solution Suggestions (Sanliurfa Sample)}

\begin{abstract}
The Harran Plain located within the province of Şanlıurfa, with its fertile soil, is an area with quite advantageous opportunities not only for crop but also for animal production. However, poverty is seriously felt in the rural area of Şanlıurfa province. With a protocol signed between the General Directorate of Social Assistance and Solidarity and the Ministry of Food, Agriculture and Livestock in 2003, Social Support Project in Rural Areas (KASDEP) has been put into practice. By the help of this project, 19 cattle farming cooperatives that have an average of 80-90 members were established in Şanlıurfa after 2005. However, all of these cooperatives have finalized their activities at the moment and have been in past due as they couldn't repay their state loans. In this study, breeding cattle farming cooperatives established in Şanlıurfa are investigated within the scope of KASDEP. Focus group discussions have been made with the directors and members of the cooperatives during the research process. As a result of the data obtained through interviews, observations and evaluations; problems and closing reasons of the breeding cattle farming cooperatives established within the scope of KASDEP have been determined. In light of these determinations, necessary applications and politics have been recommended in order the activities of breeding cattle farming and agricultural cooperatives to be successful in Şanlıurfa.
\end{abstract}

Keywords: Şanlıurfa, Agricultural Organization, Cooperative, Livestock 


\section{Giriş}

Gelişen ve değişen dünyada insanoğlunun önemli ve değişmez sorunlarının başında yeterli ve dengeli beslenme gelmektedir. Ülkelerin kalkınmasında, sağlıklı bireylerin ve beyinlerin yetişmesinde yeterli beslenme önemli bir faktördür. Toplumun refah seviyesinin göstergelerinden birisi de, insanların yaşamları için gerekli gıda ürünlerine kolay ve ucuz bir şekilde ulaşabilmeleridir. Gıda ürünleri içerisinde özellikle hayvansal ürünler besin değerleri açısından vazgeçilmez ve diğer besin maddeleri ile ikame edilemez bir konumdadır.

İnsanın büyümesi, gelişmesi ve sağlıklı kalabilmesinin yanı sıra, beyin gelişimi bakımından da önemli olan sekiz adet aminoasit, sadece hayvansal kökenli proteinlerde yeterli miktarda bulunmaktadır. Dünya Sağlık Örgütü (WHO) verilerine göre sağlıklı bir insanın vücut ağırlığının her kilogramı için günde $1 \mathrm{gr}$ protein tüketmesi ve bunun da \%42'sinin hayvansal kökenli olması gerekmektedir. Hayvansal besinlerdeki protein miktarlarl; ette $\% 15$ - 20, balıkta \%19 - 24 , yumurtada $\% 12$, sütte $\% 3-4$, peynirde $\% 15$ - 25'dir. Bunun için süt, yumurta, kırmızı et ve beyaz etin günlük olarak düzenli olarak tüketilmesi gerekmektedir. Gelişmiş ülkelere baktığımızda kişi başına günlük protein tüketimi 102 gr olup, bunun 70 gramı hayvansal kaynaklı proteinlerden oluşmaktadır. Ülkemizde yaklaşık 84 gr olan kişi başına protein tüketiminin ise ancak 17 gramı hayvansal kaynaklı proteinlerden karşılanmakta, yani ülkemizde tüketilen günlük protein miktarının $\% 73$ 'ü bitkisel gıdalardan sağlanmaktadır (Kutlu ve ark., 2003).

Türkiye, coğrafi ve iklim yapısı sebebiyle hemen hemen her türlü bitkinin yetişmesine uygun özellikte ve tarımsal üretimde dünyadaki kendi kendine yeterli az sayıda ülkelerden biridir. Tarımsal üretim faaliyetleri içerisinde, bazı bölgelerde doğa ve iklim yapısının uygunluğu hayvancılık faaliyetlerinin de verimli bir şekilde yürütülmesine imkân sağlamaktadır.

Kaliteli ve bol miktarda üretilen hayvan ve hayvansal ürünler, her zaman dış ticarete açık ürünler olup, bu ürünlerden önemli döviz girdisi de sağlanabilmektedir. Nitekim ABD, Almanya, Ingiltere, Hollanda, Danimarka, Avustralya, Yeni Zelanda ve Fransa gibi hayvancılığı gelişmiş olan birçok ülke bu yolla önemli kazançlar sağlamaktadır. Anılan ülkeler, hayvancılığı gelişmemiş olan ülkelere hayvansal ürünler satabildikleri gibi, teknoloji, damızlık hayvan, sperma veya embriyo satışı da yapabilmektedir (Saçlı, 2005).

Hayvancllık, ülke ekonomisini geliştiren, birim yatırıma en yüksek katma değer oluşturan ve en düşük maliyetle istihdam imkânı sağlayan bir sektördür. Sanayide günümüzde bir kişiye istihdam olanağı yaratabilmek için asgari 80 bin dolarlık yatırıma ihtiyaç duyulurken, hayvancilıkta bunun beşte biri kadar kaynak yeterli olmaktadır. Sanayi kesimi ile karşılaştırıldığında aynı miktar yatırım ile hayvancılıkta 5 kat daha fazla sayıda kişiye iş imkânı yaratılabilmektedir (Peşmen ve Yardımcı, 2008).

Ülkemizde tarımsal istihdamın oranı yaklaşık \%20 gibi oldukça yüksek bir düzeydedir (TÜiK, 2016b). Bu oran ABD'de $\% 2$ ve $A B^{\prime}$ de \%4.7'dir. Tarımın Gayri Safi Milli Hasıla (GSMH) daki payı ülkemizde \%7.4 iken, $A B D$ ve $A B^{\prime}$ de sırasıyla $\% 1$ ve $\% 1.8$ seviyelerindedir. Bu oranlar ülkemiz açısından tarım sektörünün ne kadar önemli olduğunu ve sorunların öncelikle çözüm gerektirdiğini göstermektedir (Worldbank, 2013).

Şanlıurfa ilinde tarım alanlarının miktarı 1200573 hektar (toplam ilin \%64.1) kadardır. 
Şanlıurfa ili, genel arazi bölünüşü içerisinde tarım alanları bakımından hem Türkiye'deki tarım alanlarına (\%36), hem de GAP Bölgesi'ndeki tarım alanlarına (\%43.6) göre daha avantajlı bir orana (\%64.1) sahiptir. Ayrıca il, bölgedeki toplam tarım alanlarının \%36.2'sini, Türkiye'deki tarım alanlarının ise $\% 4.2$ 'sini oluşturmaktadır. Bu büyük potansiyelinden dolayıdır ki Şanlıurfa ili, GAP içerisinde "tarım ve tarıma dayalı ihracat üssü" olarak değerlendirilmektedir (Benek, 2006).

Yüzölçümü içindeki tarım alanı incelendiğinde alt bölgeler sıralamasında en fazla tarım alanı \%70 ile TRC21 II'de (Birecik, Bozova, Halfeti ve Suruç) bulunmaktadır. Bunu sırasıyla TRC21 III (Hilvan, Siverek, Viranşehir) ve TRC21 I (Merkez, Akçakale, Ceylanpınar ve Harran) izlemektedir. Çayır mera alanlarına bakıldığında ise, Şanlıurfa yüzey alanının \%13'ü mera alanı iken, bu oran Türkiye genelinde $\% 26$ 'dır. Şanlıurfa ülke geneline göre $\% 50$ oranında mera alanından yoksundur. Alt bölge yüzölçümüne göre en fazla mera alanı III. Alt bölgede bulunmaktadır. Bunu sırayla II ve I. Alt bölgeler izlemektedir. Orman varlığı bakımından Şanlıurfa yüzölçümünün \%0.6'lık alanına tekabül eden $11817 \mathrm{ha}$ alan ile ülkenin orman ve fundalık alanı bakımından fakir ilidir. Var olan orman varlığı da en fazla TRC21 III. alt bölgede bulunmaktadır. Tarım dışı alanların ülke geneli ile mukayese edildiğinde Türkiye'de \%13, Şanlıurfa'da ise \%27 oranında tarım dışı arazi olduğunu görmekteyiz. Şanlıurfa'da, Türkiye genelinin üzerinde \%14 oranında değerlendirilmeyen arazi bulunmaktadır. Sonuç olarak, Şanlıurfa tarımsal bakımdan önem taşıyan tarım alanı itibariyle Türkiye ortalamasının üstünde, çayır - mera alanı ve orman - fundalık bakımından zayıf ve ülke ortalamasının altında görülmektedir. Tarım dışı arazi bakımından ise ülke ortalamasının üstünde bir değere sahiptir (Karaağaç ve ark., 2006).

Türkiye İstatistik Kurumu (TÜiK) resmi kayıtlarına göre Şanlıurfa ilinde 2015 yılı sonu itibari ile toplam 221735 büyükbaş hayvan bulunmaktadır. Bu rakam Türkiye'de ki toplam büyükbaş hayvan sayısının \%1.56'sına karşılık gelmektedir. Arazi verimliliği ve Şanlıurfa ilinin Nüfus yoğunluğu dikkate alındığında büyükbaş hayvancılık konusunda Şanlıurfa ilinin faaliyet düzeyi istenilen seviyeye gelememiştir (TÜiK, 2016b).

Bölgede son beş yıla kadar sadece küçükbaş hayvancılık yoğun olarak yapılmakla beraber, uygulanan tarım politikaları ve hibe programları ile büyükbaş hayvan yetiştiriciliği yapan işletme sayısı arttırılmaya çalışılmış, bu sayede hayvancılık ile ilgili diğer faaliyet alanlarının (yem bitkisi üretimi, süt ve et entegre tesisleri vb.) gelişimi için çaba sarf edilmiş ve kırsalda yoksullukla mücadelede kırsalda örgütlü hareket kabiliyeti arttırılmaya çalışılmıştır.

Kırsalda örgütlenme denilince akla ilk gelen tarım kooperatifleridir. Tarımsal amaçlı kooperatif projelerinin amacı; Gıda, Tarım ve Hayvancılık Bakanlığı (GTHB) görev alanına giren 1163 Sayılı Kooperatifler Kanunu'na göre kurulan tarımsal amaçlı kooperatiflerin uygulamak istedikleri projelere teknik ve kredi desteği sağlayarak, kırsal alanda üretici ve yetiştiriciler arasında birlikteliği güçlendirmek, bitkisel ve hayvansal üretimde verimliliği ön planda tutarak, rekabet üstünlüğüne haiz pazar değeri olan ürünlerin üretilmesi, işlenmesi ve tarımsal istihdamın artırılmasına katkı sağlayacak ileri teknolojide işletmelerin kurulmasına yardımcı olmaktır. GTHB'nin görev alanında bulunan ve 1163 Sayılı Kooperatifler Kanununa göre kırsal alanda kurulan tarımsal amaçlı kooperatiflerin projeli faaliyetleri 1967, 1974, 1990 ve 2001 yıllarında olmak üzere çıkarılan 
4 yönetmelik çerçevesinde yapıla gelmiştir.

Yürürlükte olan tarımsal amaçlı kooperatiflere kullandırılacak kredilere ilişkin yönetmeliğe göre işlemler sürdürülmektedir. Kooperatiflerin uyguladığı projelerin desteklenmesi ve takip-tahsil görevi Projeler ve Kredilendirme Daire Başkanlığı tarafından yürütülmektedir (Anonim, 2015).

Çizelge 1. Şanlıurfa illinde 2009 - 2015 Yılları Arası Büyükbaş Hayvan Sayısı

Table 1. The Number of Cattle Between 2009 and 2015 in Şanlıurfa Province

\begin{tabular}{|c|c|c|c|c|c|}
\hline \multirow{2}{*}{$\begin{array}{c}\text { Yıllar } \\
\text { Years }\end{array}$} & \multicolumn{5}{|c|}{$\begin{array}{c}\text { Büyükbaş Hayvan Sayısı } \\
\text { Number of Cattle }\end{array}$} \\
\cline { 2 - 6 } & $\begin{array}{c}\text { Sığır } \\
\text { Cattle }\end{array}$ & $\%$ & $\begin{array}{c}\text { Manda } \\
\text { Mandate }\end{array}$ & $\%$ & $\begin{array}{c}\text { TOPLAM } \\
\text { TOTAL }\end{array}$ \\
\hline $\mathbf{2 0 0 9}$ & 146931 & 99.42 & 855 & 0.58 & 147786 \\
\hline $\mathbf{2 0 1 0}$ & 176780 & 99.72 & 490 & 0.28 & 177270 \\
\hline $\mathbf{2 0 1 1}$ & 187054 & 99.78 & 415 & 0.22 & 187469 \\
\hline $\mathbf{2 0 1 2}$ & 179076 & 99.77 & 414 & 0.23 & 179490 \\
\hline $\mathbf{2 0 1 3}$ & 196574 & 99.79 & 420 & 0.21 & 196994 \\
\hline $\mathbf{2 0 1 4}$ & 222916 & 99.89 & 244 & 0.11 & 223160 \\
\hline $\mathbf{2 0 1 5}$ & 221456 & 99.87 & 279 & 0.13 & 221735 \\
\hline
\end{tabular}

Kaynak: Türkiye İstatistik Kurumu (TÜiK), 2016a.

GTHB ile şu anda kapatılmış olan Sosyal Yardımlaşma ve Dayanışma Genel Müdürlüğü’nün bağlı olduğu Devlet Bakanlığı arasında 2003 yılından itibaren 5 yıl süreli bir işbirliği protokolü imzalanmıştır. Bu protokole dayanılarak uygulamaya konulan Kırsal Alanda Sosyal Destek Projesiyle (KASDEP), yoksul kişi ve ailelerin kooperatif şeklinde örgütlenerek uygulayacakları süt sığırcılığı, koyunculuk, kırsal ve tarımsal amaçlı diğer projelerin desteklenmesi öngörülmüştür. Projeyle; GTHB organizasyon alt yapısı ile Sosyal Yardımlar Genel Müdürlüğünün maddi kaynakları bir araya getirilmiş ve kamu kaynaklarının en etkili şekilde kullanılması olanağı ortaya çıkmıştır. Protokol 2005 yılında revize edilmiş ve 2010 yılında sona ermiştir. 2010 yılından sonra projeye yeni kooperatif alınmamıştır. Ancak daha önce programa alınan kooperatiflerin işlemleri devam etmektedir (Anonim, 2015).

Bu çalışmada öncelikli olarak; KASDEP kapsamında Şanlıurfa ilinde kurulan damızlık sığır yetiştiriciliği kooperatiflerinin genel durumları ve yaşadıkları sorunlar tespit edilmiştir. Sonrasında ise tespit edilen sorunların çözülmesi ve kooperatiflerin fonksiyonel işlerlik kazanabilmeleri için yapılması ve uygulanması gereken önerileri belirlenmiştir.

\section{Materyal ve Metot}

Çalışmanın ana materyalini; 2005 yılı sonrası Şanlıurfa ilinde KASDEP kapsamında kurulan damızlık sığır yetiştiriciliği (süt sığırcılığı) kooperatifleri oluşturmuştur. 2005 yılı sonrası KASDEP kapsamında Şanlıurfa ilinde kurulan süt sığırcılığı sayısının 19 adet olduğu tespit edilmiştir. Odak grup görüşme yöntemi kullanılarak, kooperatif yöneticileri ile görüşülmüş, ancak 3 kooperatifin yöneticilerine veya temsilcilerine ulaşılamamıştır. Odak grup görüşmeleri, bir grup içindeki alt grupların kendilerinin de bilinçli, yarı bilinçli veya bilinçsiz oldukları psikolojik ve sosyo - kültürel özellikler ve yaptıkları uygulamalar hakkında bilgi almayı, 
davranışları ve bu davranışların arkasındaki nedenleri öğrenmeyi amaçlayan niteliksel bir yöntemdir. Odak grup görüşmeleri, genel olarak grup tartışmaları içinde amacı, kompozisyonu, ve izlenen süreç açısından özel bir yapı gösterir. Odak grup görüşmeleri, "izin veren ve ürkütücü olmayan bir ortamda belli bir konuya ilişkin algıları öğrenmek amacı ile dikkatlice planlanmış tartışmalar olarak" tanımlanabilir (Şahsuvaroğlu ve Ekşi, 2008).

Damızlık sığır yetiştiriciliği kooperatif yöneticileri ile 4 ayrı grup halinde (Siverek,
Bozova, Birecik ve Merkez) görüşmeler yapılmış, bu görüşmeler sonucunda ihtiyaç duyulan veriler bilgi sahibi olan kooperatif yöneticilerinden ve üyelerinden alınmıştır. Her ilçede birer grup toplantısı yapılarak o ilçelerdeki her kooperatif yöneticisi ile ve bu kooperatife kayıtlı olan üyeler ile görüşmeler yapılmıştır. Görüşme yapılan toplam kooperatif yöneticisi sayısı 16 olup, kooperatif üye sayısı ise $30^{\prime}$ dur.

Çizelge 2. Görüşme Yapılan Gruplardaki Kişi Sayıları

Table 2. Number of People in The Groups Interviewed

\begin{tabular}{|l|c|c|c|}
\hline $\begin{array}{c}\text { illçeler } \\
\text { Districts }\end{array}$ & $\begin{array}{c}\text { Grup Sayısı } \\
\text { The Number of } \\
\text { Groups }\end{array}$ & $\begin{array}{c}\text { Görüşme Yapılan Yönetici Sayısı } \\
\text { The Number of Executives } \\
\text { Interviewed }\end{array}$ & $\begin{array}{c}\text { Görüşme Yapılan Üye Sayısı } \\
\text { The Number of Members } \\
\text { Interviewed }\end{array}$ \\
\hline Merkez & 1 & 5 & 8 \\
\hline Birecik & 1 & 2 & 6 \\
\hline Bozova & 1 & 4 & 7 \\
\hline Siverek & 1 & 5 & $\mathbf{3 0}$ \\
\hline TOPLAM & $\mathbf{4}$ & $\mathbf{1 6}$ & 9 \\
\hline
\end{tabular}

\section{Araştırma Bulguları ve Tartışma}

\section{Kooperatifler Ille Ilgili Genel Bilgiler}

KASDEP kapsamında Şanlıurfa ilinde faaliyette bulunan Sosyal Yardımlaşma ve Dayanışma dernekleri ile GTHB il/ilçe müdürlükleri ortak çalışarak; daha önce hayvancilık faaliyetleri ile uğraşmış/uğraşmakta olan, gelir seviyesi düşük, arazi varlığı olmayan aileler tespit edilmiştir. Tespit edilen ailelerin kooperatif kurmaları sağlanarak her aileye belli sayıda süt sığırı teslim edilmiştir. Teslim edilen süt sığırları bedeli ve süt sığırcılığı faaliyetleri için gerekli olan makine alımı, ahır yenileme giderleri karşılığında aileler kooperatif adına

${ }^{1}$ Müteselsil borç, bir alacaklının birden çok borçlusu bulunan alacağının tümünü, bu borçluların her birinden bütünüyle isteyebilmesine imkân veren bir yapıyı ifade eder. Bu yapı içinde müteselsil borçluların her biri, borcun tamamı
Ziraat Bankası'na müteselsilen ${ }^{1}$ borçlandırılmışlardır.

Kooperatif aracılığı ile alınan sertifikalı süt sığırları iki farklı şekilde kurulan ahır sistemi ile yetiştirilmeye başlanmıştır. Bazı kooperatifler her üyenin kendisine ait olan ahırları kullanıp (gerekli ahır iyileştirilmeleri yapılarak) süt sığırlarını ailelere dağıtırken, bazı kooperatifler alınan süt sığırlarını tek bir ahırda toplayarak faaliyetlerine devam etmişlerdir. 16 kooperatiften 11 tanesi süt sığırlarını kooperatif üyelerine dağıtırken, beş kooperatifte süt sığırları tek bir ahırda toplanmış ve kooperatif faaliyetleri tek ahır şeklinde devam etmiştir. Kooperatifler ortalama iki üç yıl faaliyetlerine devam etmiş

ödeninceye kadar sorumlu kalmaya devam eder. Bu tür borç ilişkilerinde müteselsil borçluların tümünün sorumluluğu şahsi niteliktedir ve borcun tümünü kapsar (Akın, 2011). 
ancak daha sonra faaliyetlerini sonlandırmışlardır.

Yapılan odak grup görüşmelerinde KASDEP kapsamında açılan kooperatiflerin tamamının kapandığı ve vadesi gelen borçların ödenmemesi dolayısıyla kooperatif yöneticilerinin ve üyelerinin hacizlerle karşı karşıya kaldıkları görülmüştür. Kooperatiflerin ortalama 4.5 milyon TL borcu bulunmakta olup, bu borçlardan kooperatif üyesi olan ortakların tamamı müteselsilen sorumludurlar. Yani üye olan bir kişi kendisine ait olan borçların tamamını ödese dahi borçlarını ödemeyen diğer üyelerin borçlarından da sorumludurlar.

Kooperatif yöneticilerinin tamamı erkek olup, yaş ortalaması 39 dur. 4 kooperatif yöneticisi yüksekokul mezunu olup, diğer yöneticiler (12 kişi) ortaokul ve lise mezunudur. Görüşme yapılan kooperatif üyelerinin yaş ortalaması 42 olup, bu üyeler arasında üniversite mezunu bulunmamaktadır. Üyelerden $8^{\prime} i$ lise mezunu iken, 22'si ilköğretim/ortaokul mezunudur. Kooperatif üyelerinin $\% 25$ 'i kadın olmasına rağmen; kadın üyelerin görüşmek istememelerinden dolayı kadın üyeler ile odak grup görüşmesi yapılamamıştır.

Kooperatif yöneticileri ile yapılan odak grup görüşmelerinde; uygulanmaya çalışılan sistemin Şanlıurfa kırsalında yaşayan ailelerin yoksulluktan kurtarılması için önemli olduğu, ancak uygulamada eksik yönlerin bulunduğu ve bu eksiklikler dolayısıyla kooperatiflerin kapanma durumu ile karşı karşıya kaldıkları görüşü ortaya çıkmıştır.

\section{Kooperatiflerin Başarısızlık Nedenleri}

Kooperatif Sistemine Katıım Şekli ve Üyelerin Niteliği

Kooperatife üye olan kişilerin bir kısmı hayvancilık ile ilgisi olmayan, kooperatife alınacak hayvan sayısını arttırmak amacıyla ikili ilişkiler çerçevesinde üye yapılan kişilerden oluşmaktadır. Bu kişilerin bir kısmı alınacak olan hayvan bedeli ve yapılacak olan masraflar dolayısıyla borçlanacaklarının dahi bilincinde değillerdir. Birçoğu kooperatife akraba veya arkadaşının isteği için üye olmuşlardır. Üye olan kişiler kooperatif sistemini, bu sistemin başarısı için gerekli olan koşullar ve üyelik ile üstlendikleri sorumluluklar hakkında en ufak bilgiye sahip değillerdir.

Kooperatif üyeleri ile yapılan odak grup görüşmelerinde, üyelerin tamamına yakınının tarımsal kalkınma kooperatiflerin işleyişleri, faaliyet biçimleri ve yasal yükümlülükleri hakkında bilgi sahibi olmadıkları görülmüştür. Üyelerin kooperatife dahil olma nedenlerinin başında bedelsiz hayvan sahibi olma isteği gelmektedir. Üyelerin tamamına yakını; dağıtılan hayvanların bedelleri ve yapılan yatırım giderleri dolayısıyla müteselsilen borçlandıklarının farkında değildir. Üyelerde oluşan algı "devlet tarafından bizlere ücretsiz hayvan dağıtıldı ve bunun karşılığında bizim herhangi bir yükümlülügümmüz yok" şeklindedir.

\section{Kooperatif Üyelerinin Ekonomik Durumu}

Şanlıurfa'da süt sığırcılığı üretim faaliyetinde bulunan işletmelerin etkinliği ile ilgili yapılan bir çalışmada işletmelerin ortalama etkinliğinin \%56 olduğu belirlenmiştir. Etkinlikte kullanılan yem karmasının ve elektrik masraflarının önemli derecede etkili olduğu belirlenmiştir (Binici ve ark., 2013).

Süt sığırcılığı yatırım maliyeti yüksek, devamlılık içinse ciddi öz kaynak ihtiyacı duyan bir tarımsal faaliyet koludur. Bir süt sığırının günlük yem maliyeti asgari 10 - $12 \mathrm{TL}$ arasındadır. İşçilik, ilaç ve veteriner masrafları dahil edildiğinde süt sığırının günlük bakım maliyeti 15 TL'ye kadar yükselmektedir. Süt 
sığııının süt verimliliği ise yine doğru yem karması ve hayvan bakımı ile doğrudan ilgilidir. Uygun koşullarda bakılan ve yemlenen sağlıklı kültür ırkı süt sığırlarının günlük süt verimi; asgari 30 litre civarındadır.

Şanlıurfa ilindeki KASDEP kapsamında kurulan kooperatiflerde süt veriminin hayvan başına günlük 20 litrenin üzerine çıkılamadığı görülmüştür. Kooperatif üyelerinin tamamı devlet yardımları ile geçimlerini sağlayan kişiler olup süt sığırının bakımı için gerekli olan nakdi sermayeye ve asgari araziye sahip değillerdir. Evlerine zor ekmek götüren bu kişilerin en az 2 süt sığırı sahibi olduğu düşünülürse, aylık ortalama $900-1000 \mathrm{TL}$ civarındaki bakım masraflarını karşılayacak ekonomik güce sahip olamadıkları görülmüştür. Dolayısıyla bakım masraflarını karşılayamayan üyelerin hayvanlarındaki süt verimi her geçen gün düşmüştür. Açlıkla karşı karşıya kalan hayvanların birçoğu telef olurken bir kısmı da zorunlu olarak kesime gönderilmiştir.

2006 yılından itibaren faaliyete başlayan kooperatifler birkaç yıllık faaliyet süresi sonucunda yem ve yem bitkileri fiyatlarında yaklaşık \%500'e yakın artışla karşı karşıya kalmışlardır. Bununla beraber süt ve et fiyatlarındaki artış yem fiyatlarındaki artışla aynı oranda olmamıştır. Bu durum özellikle kendi arazisi olmayan ve yem ihtiyacını dışarıdan satın alarak gidermeye çalışan kooperatiflerin karlıığı ve devamlılığını önemli ölçüde olumsuz etkilemiştir. Geçinmekte zorluk çeken kooperatif üyeleri yem ve yem bitkilerinin fiyatlarının yüksekliği dolayısıyla hayvanları için uyulması gereken yem karmasına uyamamış ve en ucuz yollarla hayvanlarının yem ihtiyaçlarını gidermeye çalışmıştır.

Diğer taraftan tamamı dar gelirli olan üreticilerin bir kısmı dağıtılan hayvanlar karşılı̆̆ında herhangi bir yasal yükümlülüğü olmadığını düşünerek, hayvanlarını teslim aldıktan sonra yasak olmasına rağmen satarak nakde çevirmişlerdir.

\section{Kooperatif Üyelerinin Sosyo - Kültürel Özellikleri}

Şanlıurfa'nın kırsal alanlarında feodal yapının etkisiyle toplumsal düzeni sağlamada hukuk kuralları değil, dini kurallar ve aşiret sisteminin doğurduğu adetlerin ve töre kuralları belirler. Araştırma alanındaki bireylerin toplumsal ilişkilerinde örf, adet, töre, aşiret, cemaat, ve feodal yapı kuralları oldukça etkilidir. Toplumsal yaşamın ve sosyal ilişkilerin her noktası ve aşamasında bu kuralların etkisi görülmektedir. Bu kurallar bireylerin hem birincil gruplar hem de ikincil gruplar içerisindeki ilişki ve davranışlarını belirlemektedir. $\mathrm{Bu}$ kurallarla beraber bireylerde liderlere karşı (aşiret, cemaat, tarikat vb.) sorgusuz itaat kültürü oldukça gelişmiştir.

Kooperatifçilik her üyenin sorumluluk aldığı, bireysel olarak yapılan her davranış ve hareketin kooperatifin diğer üyelerini de etkilediği bir örgütlenme biçimidir. Kooperatif üyelerinin bu çerçevede katılımcı, çalışkan, sorumluluk bilincine sahip ve kooperatifi sahiplenen aidiyet duygusu içinde hareket etmesi beklenir. Ancak kooperatif yöneticileri ile yapılan görüşmelerde, örgütlenme üzerine çeşitli eğitimlerin verilmiş olmasına rağmen; üyelerde örgüt bilincinin ve sorumluluğunun bir türlü geliştirilemediği görülmüştür. Bu durum kooperatiflerin faaliyetlerinde olumsuz sonuçlar doğurmuştur.

\section{Teknik Destek}

KASDEP kapsamında hayvan dağıtılan kooperatif üyelerinin çoğunluğu daha önce hayvancılık ile uğraşmış olan bireylerdir. Ancak bu bireylerin uğraştığı hayvancilık biçimi daha çok mera (otlatma) sistemi ile yapılan küçükbaş hayvan yetiştiriciliğidir. Süt 
sığırcılığı gerek besleme gerekse bakım teknikleri ile küçükbaş hayvan yetiştiriciliğinden ve otlatma tipi yetiştiricilikten oldukça farklıdır. Hayvan dağıtılan kooperatif üyeleri hayvanlarını aldıktan sonra adeta kaderleri ile baş başa bırakılmışlardır. Yetiştirme sürecinde yapılan bakım ve besleme hataları dolayısıyla da telafisi güç sorunlar ortaya çıkmıştır.

Gelir seviyesi düşük olan kooperatif üyeleri süt sığırlarının bakımı sürecinde zorunlu olan ilaç ve periyodik sağlık bakımlarını yapamamışlardır. Bu eksiklik süt sığırlarının sağı̆̆ı̆ı ciddi olarak etkilemiş, birçok hayvan bu nedenle telef olmuştur.

\section{Sonuçlar}

KASDEP kapsamında 2005 yılından sonra Şanlıurfa'da kurulan kooperatiflerin tamamı kısa süreler içerisinde faaliyetlerini devam ettiremeyip kapanmış ve borçlarını peşin ödeme durumuna düşmüşlerdir. Bunun sonucunda zaten dar gelirli ve yoksul olan kooperatif üyeleri, hacizler ile karşı karşıya kalmışlardır.

KASDEP'in başarısız olmasında ve kooperatiflerin kapanmasında temelde iki neden bulunmaktadır. $\mathrm{Bu}$ nedenlerden birincisi; süt sığırcılığı ile uğraşacak olan ailelerin ekonomik durumlarıdır. Kooperatif üyesi olarak kabul edilen bireylerin ve bu bireylerin ailelerinin ekonomik gelir seviyesi düşüktür. Yine bu kişilerin arazileri bulunmamaktadır. Düşük gelir ve arazi yokluğu süt sığırcılı̆̆ı faaliyetlerinin sürekliliğini olumsuz olarak etkilemiştir. İkinci neden ise kooperatif üyesi olan üreticilerin kooperatif örgütlenme sistemine anlayış ve bilgi olarak uzak olması ve kooperatifçiliğin gerektirdiği sorumlulukları yerine getirememesidir. Bölgede özellikle kırsalda kalkınma konusunda örgütlü hareket kabiliyeti, bölge insanının içerisinde bulunduğu toplumsal yapı gereği oldukça zordur. Kırsalda yaşayan bireyler kırsalda yapılan/yapılacak örgütlenme faaliyetlerine güvenmemekte, bu tarz örgütlenme biçimlerinin kendilerine ek maliyet ve yükümlülük getireceğine inanmaktadırlar. Kısacası bölgede örgütlenme bilinci gelişmemiş ve yerleşmemiştir.

Kırsalda yoksullukla mücadelede örgütlü bir hareket isteniyor ise; kurulacak olan örgüt ve kooperatiflerin devlet kontrolünde ve denetiminde kurulması, kuruluş sonrası üyelerin karşılaşacağı her türlü teknik ve ekonomik sorunlara anında müdahale edilmesi gerekmektedir. Belli bir süre sonunda kooperatif üyelerinde örgüt bilinci ve algısının geliştiği kanaatine varılınca, kooperatiflerdeki bu denetimler azaltılabilir. Bu şekildeki sıkı denetim sistemi devlet bütçesine ilave maliyetleri getirebilir ancak, başarısız örnekleri olan diğer uygulamalara kıyasla bu şekilde kooperatiflere işlerlik kazandırabilecektir. Zira uygulanan mevcut kırsalda destek ve hibe politikaları ile bir başarı sağlanamadığı gibi, ciddi miktarda kaynak israfı da söz konusudur.

\section{Kaynaklar}

Akın, L., 2011. Yeni borçlar kanunu düzenlemeleri çerçevesinde asıl işverenin müteselsil sorumluluğunun niteliği. Ankara Üniversitesi Hukuk Fakültesi Dergisi, 60 (4): $733-774$.

Anonim,2015.http://www.tarim.gov.tr/Konular/P rojeler-Ve-Kredilendirme/Projeler. Erişim tarihi: 18.02.2015

Benek, S., 2006. Şanlıurfa ilinin tarımsal yapısı, sorunları ve çözüm önerileri. Coğrafi Bilimler Dergisi, 4(1):67-91.

Binici, T., Zualuf, C.R., Özel, R., Seviç, R., Işgın, T., 2013. Assessing production efficiency of dairy farms in Şanlıurfa province, Turkey. Journal of Animal and Veterinary Advances, 12(5):621-624.

Karaağaç, A., Bilgiç, A., Çukur, Ü., 2006. Şanlıurfa Tarım Master Planı, 2015. 
http://www.tarim.gov.tr/SGB/Belgeler/Ma ster/sanliurfa.pdf. Erişim tarihi: 02 Şubat 2015.

Kutlu, H.R., Gül, A., Görgülü, M., 2016. Türkiye Hayvancılığı; Hedef 2023 - Sorunlar, Çözüm Yolları Ve Politika Arayışları. http://www.zootekni.org.tr/upload/File/H ayvanclk\%20Rapor-Sonhali.pdf. Erişim tarihi: 12 Mart 2016.

Peşmen, G., Yardımcı, M., 2008. Avrupa Birliği'ne adaylık sürecinde Türkiye hayvancılığının genel durumu. Vet Hekim Der Derg, 79 (3): $51-56$.

Saçlı,Y., 2005. Türkiye Sığırcılığında Alternatif Gelişme Olasılıkları ve Geleceğe İlişkin Politikaların Belirlenmesi Üzerine Bir Araştırma. Doktora Tezi, Ege Üniversitesi, Fen Bilimleri Enstitüsü, İzmir, 330s.

Şahsuvaroğlu, T., Ekşi, H., 2008. Odak grup görüşmeleri ve sosyal temsiller kuramı. Eğitim Bilimleri Dergisi, 28 (28): 127 - 139.

Türkiye İstatistik Kurumu (TÜIK), 2016a. Mevsim etkilerinden arındırılmış temel işgücü göstergeleri.

http://www.tuik.gov.tr/UstMenu.do?meto d=temelist. Erişim tarihi: 20.07.2016.

Türkiye İstatistik Kurumu (TÜiK), $2016 \mathrm{~b}$. https://biruni.tuik.gov.tr/hayvancilikapp/h ayvancilik.zul. Erişim tarihi: 15.03.2016.

Worldbank,2013.http://ec.europa.eu/agriculture /statistics/agricultural/2011/pdf/tablesmaps-graphs_en.pdf. Erişim tarihi: 01.03.2013. 